\title{
Influence of Profitability to the Firm Value of Diversified
}

\section{Companies in the Philippines}

\author{
William Sucuahi ${ }^{1} \&$ Jay Mark Cambarihan ${ }^{1}$ \\ ${ }^{1}$ University of Mindanao, Philippines \\ Correspondence: William Sucuahi, University of Mindanao, Philippines \\ Received: March 10, 2016 \\ Accepted: March 28, 2016 \\ Online Published: May 16, 2016 \\ doi:10.5430/afr.v5n2p149 \\ URL: http://dx.doi.org/10.5430/afr.v5n2p149
}

\begin{abstract}
The main objective of every company is to maximize the assets or firm value. Maximizing firm value is essential for a company because it means increasing the wealth of shareholders as well. This study aims to determine if there is significant influence between the company's profile such as industry, company age and its profitability with the firm value using Tobin's Q model. The proponents selected 86 diversified companies in the Philippines by gathering and analyzing annual financial reports on 2014 in the Philippine Stock Exchange (PSE) to obtain the objective of the study and also employed predictive correlational design. Frequency, Mean and Multiple Regression were used to determine the significant influence between the independent and dependent variables. The multiple regression reveals that of the three factors assumed to influence value of the firm using the Tobin's Q, only profitability shows significant positive impact on the firm's value.
\end{abstract}

Keywords: Financial Management, Firm Value, Diversification, Philippines, Tobin's Q

\section{Introduction}

Diversification and firm value remained relevant to most researchers for the past decades. This is because diversified company considers as a significant player in an emerging market (Kim, Hoskisson, Tihanya and Hong, 2004). Most of the study determines what factors can affect the firm value. It was stated that firm's wealth, technology, organization structure, human resources with discounted future cash flows (Kayali, Yereli and Ada, 2007) and environmental factors of industrial establishments (Konar, Bailly and Cohen, 2001) can affect firm value. Another study uses customer satisfaction, management understanding, technology usage, and product quality as factors that influence firm value (Düzer, 2008; and Akgüç, 1998). There are also many studies that have identified firms' competitiveness as a factor that can affect firm value (Amiri Aghdaie et al., 2012; Ansari and Riasi, 2016; Riasi, 2015a; Riasi and Pourmiri, 2015). Additionally, there are various studies that focused on sustainable growth (Riasi and Amiri Aghdaie, 2013; Riasi and Pourmiri, 2016) and firm's financing in order to determine the factors that affect firm value (Riasi, 2015b). However, most of the study used all types of firms to determine the factors of firm value. This study will focus on the firm value of diversified firms.

There is a quick improvement when it comes to buy and sell financial instruments or simply what they call capital markets (Yildiz, 2006). This may be due to efficiency and credibility in the said capital markets, which is eventually brought about by the precise determination of the firm value. Güleryüz (2009) said that a firm value was the acquisition and the trade value of the company anticipated by volunteer buyers and sellers with thorough information about the company free from any problem. Modigliani and Miller (1958) pointed out that firm value was determined by firm's asset earning power. The positive impact of asset earnings power indicated that a greater profit and efficient asset turnover if the company had higher firm's earnings power. Thus, the firm value would probably increase. Aside from the asset and profit, the company debt policy also influences firm value. The higher the debt, the higher would be its stock price.

Huang, Shih, Huang and Liu (2006) asserted promoting firms' real economic value is an important objective. Because of these, different studies were conducted to determine the factors affecting the corporate firm value. For example, Gherghina (2014) studied the relationship between corporate governance and firm value. In addition, marketers are now shifting to search on the effect of marketing on the firm value (O'Sullivan \& McCallig, 2012). This is an indicator that study on firm value is relevant in all aspects of business. This is the reason why different measurements of firm value were used. Such as Earning Capitalization Model, Market Value Added, Economic 
Value Added, Market Value of year-end stocks (Huang, Shih, Huang and Liu, 2006), Return on Asset, Earnings Per Share (Gherghina, 2014) and Tobin's Q.

To measure the value of the firm, this study used Tobin's Q. Tobin's Q measures the relationship of the firm stock market value to the firm's resources replacement cost (Sahay and Pillai, 2009). It is considered as the best predictor of market correction (Pett, 2013) and it can also explain the majority of the investment variability (Cooper and Ejarque, 2003). It can also be applied in the financial condition analysis of the company which means that the investors who acquire the firm stock would first calculate the Tobin's Q. High firm value indicated that the replacement value of the plant and equipment of the company was low and vice versa. By this situation, the companies with high Q coefficient were appropriate (Jahani, Zalghadr-Nasab and Soofi, 2013).

The purpose of the study was to determine the factors that influence the firm value of diversified listed companies in the Philippines using Tobin's Q method.

\section{Method}

\subsection{Research Design}

A predictive correlational design was employed in this quantitative research in order to determine if there is a significant influence of profile of the company on firm value using Tobin's Q. This research design was chosen because it allowed for any relationships that exist between the variables to be identified (Warner, 2013). The correlational design was appropriate because no treatments were applied to any of the participants instead; existing conditions were investigated so as to explain any potential relationships that might exist amongst the variables.

\subsection{Data}

The subject of the research involved 86 diversified listed companies in the Philippines with 2014 annual financial reports. This study used purposive sampling in selecting the subjects.

\subsection{Data Gathering Procedure}

The study was based on financial data. The main sources of these data were financial statements such as balance sheet and income statement. The variables in the study, both dependent and independent, all were calculated and drawn from financial data generated from the financial statements downloaded from the Philippine Stock Exchange webpage. The approximate Tobin's Q as proposed by Pruitt and Chung (1994) was computed using the following formula:

Approximate $\mathrm{Q}=(($ STDEBT - STASSET $)+$ LTDEBT + (No. of CS X MP $)+$ PS $) /$ TOTAL ASSET

Where:

$$
\begin{aligned}
& \text { STDEBT = short term debt } \\
& \text { STASSET = short term asset } \\
& \text { LTDEBT = long term debt } \\
& \text { CS = common shares } \\
& \text { MP = market price } \\
& \text { PS = liquidating value of preferred stock }
\end{aligned}
$$

The ideal value is one (1), which means the market value of company stocks is equal to the price of replacing the asset. Q which is lower than one means that it is more expensive to acquire the asset of the company than to acquire their stocks. In this case the company is undervalued. On the other hand, if the Q is greater than one means that purchasing company's stock is higher than purchasing their assets so the company is overvalued.

\section{Results and Discussion}

Table 1. Distribution by Industry of Diversified Firm

\begin{tabular}{lll}
\hline Industry & Frequency & Percent \\
\hline Industrial & 20 & 23.3 \\
Holding Firms & 17 & 19.8 \\
Property & 17 & 19.8 \\
Others & 32 & 37.2 \\
Total & 86 & 100.0 \\
\hline
\end{tabular}


Data (table 1) shows industry distribution of diversified listed companies in the Philippines. Industry classification was done according to their total frequency. It coincidentally showed that the industrial sector had the highest frequency which was almost one fourth of the total respondents compared to others. Also, industries such as Financials, Services, Mining and Oil, and Small, Medium and Emerging Board were the components of the others which had the least frequency.

Table 2. Distribution by Company Age of Diversified Firm

\begin{tabular}{lllll}
\hline Variable & Minimum & Maximum & Mean & Std. Deviation \\
\hline Company Age & 4.00 & 110.00 & 43.8721 & 24.80503 \\
\hline
\end{tabular}

Table 2 shows the distribution of company age or years of operation of diversified firms. The maximum company age synonymous to oldest firm was well established and more experienced when it comes to operating activities, but then it had no basis in determining their firm value.

Evans (1987) said that younger firms were more vibrant and unstable in their growth experience than older firms. However, Driffield et al. (2007) mentioned that older firms, though, may be less open to new technology as well as more inflexible in terms of smartness and effectiveness of managerial supremacy.

Table 3. Distribution by Profitability of Diversified Firm

\begin{tabular}{lllll}
\hline Variable & Minimum & Maximum & Mean & Std. Deviation \\
\hline Profitability & -.16 & .45 & .0502 & .07935
\end{tabular}

The minimum profitability which was measured by Return on Assets shows that some companies still have negative ROA. It means they were having a net loss in the balance sheet period. In other words, the company cannot compete and gain profit from the utilization of company assets (Hidayah, 2014). The Return on Assets reflected how well a company management was using the company real investment resources to generate profits. Also, it was widely used to compare the efficiency and operational performance of the company as it looked at the returns generated from the assets financed by the company (Kaguri, 2013).

Table 4. Firm Value of Diversified Companies using Tobin's Q

\begin{tabular}{llrll}
\hline Variable & Minimum & Maximum & Mean & Std. Deviation \\
\hline Tobin's Q & .00 & 9.35 & 1.1995 & 1.20250
\end{tabular}

Table 3 shows the Tobin's Q of diversified companies. The lowest firm value using Tobin's $Q$ means that the cost to replace a firm's assets was greater than the value of its stock. This implies that the stock was undervalued. Conversely, the highest firm value means that a firm's stock was more expensive than the replacement cost of its assets, which implies that the stock was overvalued.

According to Salehi (2002), if Tobin's Q ratio is more than 1, this implies that investment in assets leads to the earnings is more than their capital expenditures. Conversely, if Tobin's Q ratio is less than 1, this means that investment in assets rejects. The Tobin's Q Tobin (1969), which is a method to ease investment analysis, was mainly used to simplify an investment analysis and used as a measure of how to make worthy investments. When the firm value is higher than one, the firm has some control of intangible assets, but if it's lower than one, the firm has to pay more than it gets. A value of one explains that the company neither makes a profit nor a loss.

In addition, Allayanis and Weston (2001) stated that the firm's Tobin's Q ratio may persist high since they undertake only positive Net Present Value (NPV) projects if management drop investment projects as they were not able to obtain the required financing. Also, it's most likely to be capital constrained and may thus have a lower Q if a firm pay dividend.

Table 5. Estimates of Firm Value using Multiple Regression

\begin{tabular}{lllll}
\hline Model & & B & Std. Error & Sig. \\
\hline & (Constant) & .680 & .357 & .060 \\
& Industry & .124 & .099 & .215 \\
& Company Age & -.004 & .005 & .389 \\
& Profitability & 7.216 & 1.488 & .000 \\
\hline
\end{tabular}

R-Square: 0.23

Std. Error of Estimate: 1.07 
The multiple regression reveals that of the three factors assumed to influence value of the firm using the Tobin's Q, only the profitability of the business was able to statistically affect the firm value using the Tobin's Q. Different investigators concluded that profitability has significant influence on firm value (Bartram et al. 2011; Naito and Laux 2011).

The R-squared result shows that 23 percent of the firm value can be explained by the regression model, the rest can be explained by other factors. Multiple determination coefficient (R2) disclosed impact levels of all variables encompassed in the scope of the study on firm value and it was an index, which shows whether the sample regression line suitable for the data or not at all (Gujarati, 2006).

\section{Conclusions}

One of the duties of the firm management is to create value for their stockholders. Research on value creation must be prioritized to help the companies enhance their competitive advantage. Based on the result, profitability can influence the firm value using Tobin's Q. This means that improving firm performance can create value to the firm. The result signifies that having a good firm value attracts more investors and other parties' interests to take part of the company. Thus, it is important to determine first a company's firm value for a reliable investment.

\section{References}

Akgüç, O. (1998). Financial Management, Avcıol Publication, 7th Edition, Istanbul.

Allayanis, G., \& Weston, J. P. (2001). The Use of Foreign Currency Derivatives and Firm Market Value. The Review of Financial Studies, 14(1), 243-276. http://dx.doi.org/10.1093/rfs/14.1.243

Amiri Aghdaie, S. F., Seidi, M., \& Riasi, A. (2012). Identifying the Barriers to Iran's Saffron Exporty Using Porter's Diamond Model. International Journal of Marketing Studies, 4(5), 129-138. http://dx.doi.org/10.5539/ijms.v4n5p129

Ansari, A., \& Riasi, A. (2016). An Investigation of Factors Affecting Brand Advertising Success and Effectiveness. International Business Research, 9(4), 20-30. http://dx.doi.org/10.5539/ibr.v9n4p20

Bartram, S. M., Brown, G. W. \& Conrad, J. (2011). The Effects of Derivatives on Firm Risk and Value. Journal of Financial and Quantitative Analysis, 46, 967-999. http://dx.doi.org/10.1017/S0022109011000275

Chung, K \& Pruitt S. (1994). A simple approximation of Tobin's Q. Financial Management, 23(3), 70-74. http://dx.doi.org/10.2307/3665623

Driffield, N., Mahambre, V., \& Pal, S. (2007). How Does Ownership Structure Affect Capital Structure and Firm Value? Recent Evidence from East Asia. Cedi Discussion Paper Series, Working Paper No. 07-04. 1-43. http://dx.doi.org/10.1111/j.1468-0351.2007.00291.x

Düzer, M. (2008). The Ratios Used in Financial Analysis and Firm Value Relations, an Application on the ISE, Sakarya University, SBA, M.Sc., Istanbul. Retrieved on January 4, 2015 from http://docplayer.biz.tr/storage/24/4242537/4242537.pdf

Evans, D. S. (1987). Tests of Alternative Theories of Firm Growth. Journal of Political Economy, 95(4), 657-674. http://dx.doi.org/10.1086/261480

Gherghina, S. C. (2015). Corporate governance ratings and firm value: Empirical evidence from the bucharest stock exchange. International Journal of Economics and Financial Issues, 5(1), 97-110. Retrieved from http://search.proquest.com/docview/1651309744? accountid=31259

Gujarati, D. N. (2006). Basic Econometrics, Trans.: Şenesen, hope, Şenesen, Gulay. Literature Publishing, 4th Edition, Istanbul.

Güleryüz, F. (2009). Value Based Management. Asomedy in March. Retrieved on February 15, 2015 from http://www.aso.org.tt/kurumsal/media/kavnak/TUR/asomedva/mart2005/buvutec mart2005.html

Hidayah, N. (2014). The Effect of Company Characteristics toward Firm Value in the Property and Real Estate Company in Indonesia Stock Exchange. International Journal of Business, Economics and Law, 5(1) (Dec.), 1-8. Retrieved on January 4 4, 2015 from http://ijbel.com/wp-content/uploads/2015/01/ACC-12-The-Effect-of-Company-Characteristic-Toward-Firm-Val ue-In-The-Property-And-Real-Estate-Company-In-Indonesia-Stock-Exhange.pdf

Huang, H., Shih, H., Huang, H. \& Liu, C (2006). Can knowledge management creates firm value? Empirical evidence from United States and Taiwan. The Business Review, Cambridge, 5(1), 178-183. 
Jahani, A. M., Zalghadr-Nasab M-R., \& Soofi, F. (2013). A Survey of the Relation between Tobin's Q with Earnings Forecast Error and Economic Value Added in TSE. Advances in Environmental Biology, 7(10) Oct 2013, pp. 2795-2802. Retrieved on January 4, 2015 from http://www.aensiweb.com/old/aeb/2013/2795-2802.pdf

Kaguri, A. (2013). Relationship Between Firm Characteristics and Financial Performance of Life Insurance Companies in Kenya. pp.1-58. Retrieved on January 4, 2015 from http://chss.uonbi.ac.ke/sites/default/files/chss/AGNES\%20WANGUI\%20KAGURI_0.pdf

Kayali, C. A., Yereli, A. N., \& Ada, S. (2007). A Study The effect of Intellectual Capital on Firm Valuation with the Help of the Value Added Intellectual Coefficient of Ante Pulic. Management and Economics CB., 14(I), Manisa, 2007. 68. Retrieved on January 4, 2015 from http://www2.bayar.edu.tr/yonetimekonomi/dergi/pdf/C14S12007/CKAYSA.pdf

Kim, J. Y., Kwak J., \& Lee K. (2015). Estimating Tobin's Q for the Listed Firms in Korea, 1980-2005: Comparing Alternative Approaches and an Experiment with Investment Functions. Seoul Journal of Economics, 28(1). $\begin{array}{lllll}\text { Retrieved on } & \text { January } & 4, & 2015 & \text { from }\end{array}$ http://poseidon01.ssrn.com/delivery.php?ID=47900410002607400508801612012011509005606908508002802 702307201908109100500709606610500404202605705100711711410208410611401406704504705604804807 102809511410809007507305801407106410907211607500508709910211606812511300010109612610800501 $7031096126111087090 \& \mathrm{EXT}=\mathrm{pdf}$

Kim, H., Hoskisson, R., Tihanya, L. \& Hong, J. (2004). The evolution and restructuring of diversified business groups in emerging markets; The lessons form Chaebols Korea. Asia Pacific Journal of Management, 21(1-2), 25-48. http://dx.doi.org/10.1023/B:APJM.0000024076.86696.d5

Konar, S., Bailly, H., \& Cohen, M. A. (2001). Does the Market Value Environmental Performance?. The Review of Economics and Statistics, 83(2), 281-289. http://dx.doi.org/10.1162/00346530151143815

Modigliani, F., \& Miller M. H. (1958). The cost of capital, corporation finance and the theory of investment. The American Economic Review, 48(3), 261-297. Retrieved on January 8, 2015 from http://links.jstor.org/sici?sici=0002-8282\%28195806\%2948\%3A3\%3C261\%3ATCOCCF\%3E2.0.CO\%3B2-3

Naito, J., \& Laux, J. (2011). Derivatives Usage: Value-Adding or destroying?. Journal of Business and Economics Research, 9, 41-50. http://dx.doi.org/10.19030/jber.v9i11.6499

Ovtchinnikov, A.V. (2010). Capital structure decisions: Evidence from deregulated industries, Journal of Financial Economics, 95, 249-274. http://dx.doi.org/10.1016/j.jfineco.2009.10.003

Riasi, A. (2015a). Barriers to international supply chain management in Iranian flower industry. Management Science Letters, 5(4), 363-368. http://dx.doi.org/10.5267/j.msl.2015.2.005

Riasi, A. (2015b). Competitive Advantages of Shadow Banking Industry: An Analysis Using Porter Diamond Model. Business Management and Strategy, 6(2), 15-27. http://dx.doi.org/10.5296/bms.v6i2.8334

Riasi, A., \& Amiri Aghdaie, S. F. (2013). Effects of a Hypothetical Iranian Accession to the World Trade Organization on Iran's Flower Industry. Consilience: The Journal of Sustainable Development, 10(1), 99-110. http://dx.doi.org/10.7916/D8HQ3ZK8

Riasi, A., \& Pourmiri, S. (2015). Effects of online marketing on Iranian ecotourism industry: Economic, sociological, and cultural aspects. Management Science Letters, 5(10), 915-926. http://dx.doi.org/10.5267/j.msl.2015.8.005

Riasi, A., \& Pourmiri, S. (2016). Examples of Unsustainable Tourism in Middle East. Environmental Management and Sustainable Development, 5(1), 69-85. http://dx.doi.org/10.5296/emsd.v5i1.8705

Salehi, A. (2002). The effect of correlation between simple Tobin's $Q$ and other modifications of $Q$ in evaluating the performance of listed firms in Tehran Stock Exchange. Master Thesis, University of Allameh Tabatabai.

Tobin, J. (1969). A General Equilibrium Approach to Monetary Theory. Journal of Money, Credit and Banking, 1(1), 15-29. http://dx.doi.org/10.2307/1991374

Warner, R. M. (2013). Applied statistics: From bivariate through multivariate techniques (2 ${ }^{\text {nd }}$ ed.). Thousand Oaks: Sage Publications, Inc.

Yildiz, F. (2006). Birlesmelerde Firma Degerinin Belirlenmesi ve Birlesmenin Satin Alan Firmanin Hisse Senedi Performansma Etkileri Üzerine Bir Uygulama, Erciyes Un. SBE, Yüksek Lisans Tezi, Kayseri. Retrieved on March 25, 2015 from http://www.cluteinstitute.com/ojs/index.php/JBER/article/viewFile/5636/5717 